Серебренніков Б. С.

канд. економ. наук, дочент

Національний технічний університет Украӥни "КПІ"

\title{
ФАКТОРИ ТА СКЛАДОВІ КОНКУРЕНТОСПРОМОЖНОСТІ ЕЛЕКТРОЕНЕРГЕТИЧНИХ ТОВАРІВ НА МІЖНАРОДНИХ РИНКАХ
}

\author{
ФАКТОРЫ И СОСТАВЛЯЮЩИЕ КОНКУРЕНТОСПОСОБНОСТИ \\ ЭЛЕКТРОЭНЕРГЕТИЧЕСКИХ ТОВАРОВ НА МЕЖДУНАРОДНЫХ РЫНКАХ
}

\section{FACTORS AND COMPONENTS OF ENERGY GOODS COMPETETIVNESS IN FOREIGN POWER MARKETS}

У статті з урахуванням пріоритетів середньо- та довгострокової енергетичної політики ЄС визначено ключові сучасні складові конкурентоспроможності електроенергї на європейських енергетичних ринках, серед яких: ичінова; технічна; екологічна; інституиійна. Зроблено висновок про дочільність їх урахування при формуванні напрямів удосконалення державної секторальної та корпоративної зовнішньоторговельних політик. Ідентифіковано комплекс внутрішніх та зовнішніх факторів конкурентоспроможності електроенергї̈, виробленої в Украӥні, на європейських ринках для моніторингу, аналізу й прогнозування їхньої динаміки, комплексного обтрунтування рімень, спрямованих на розвиток та реалізацію експортного потенціалу електроенергетики Украйни. Обгрунтовано основні фактори перспективної динаміки внутрішніх иін на електроенергію. Очінено цінову конкурентоспроможність електроенергї, виробленої в Україні, на європейських ринках та виявлено існування запасу цінових конкурентних переваг в діапазоні 20-30\%. Зроблено висновок про можливість його зростання в середньостроковій перспективі, особливо враховуючи девальвацію національної валюти.

Ключові слова: фактори конкурентоспроможності, експортний потенціал, електроенергетичні ринки, електроенергія, ціна.

В статье с учетом приоритетов средне- и долгосрочной энергетической политики EC, определены ключевые современные составляющие конкурентоспособности электроэнергии на европейских энергетических рынках, среди которых: иеновая; техническая; экологическая; институичональная. Сделано вывод о иелесообразности их учета при формировании направлений совершенствования государственной секторальной и корпоративной внешнеторговых политик. Идентифицировано комплекс внутренних $и$ внешних факторов конкурентоспособности электроэнергии, производимой в Украине, на европейских рынках для мониторинга, анализа и прогнозирования их динамики, комплексного обоснования решений, направленных на развитие и реализацию экспортного потенциила электроэнергетики Украины. Обоснованы основные факторы перспективной динамики внутренних цен на электроэнергию. Оченено иеновую конкурентоспособность электроэнергии, производимой в Украине, на европейских рынках и выявлено наличие запаса ценовых конкурентных преимуществ в диапазоне 20-30\%. Сделано вывод про возможность его увеличения в среднесрочной перспективе, особенно учитьвая девальвацию национальной валюты.

Ключевые слова: факторы конкурентоспособности, экспортный потенциал, 
электроэнергетические рынки, электроэнергия, цена.

Taking into account the priorities of the medium- and long-term energy policy of the EU, the paper defines key modern components of electric power competitiveness in the European power markets, including: price; technical; environmental; institutional, that allows to develop ways of improving the state sector and corporate energy foreign trade policy. A complex of internal and external factors of Ukrainian electric power competitiveness in the European power markets was identified for monitoring, analysis and forecasting of its dynamics and integrated decision making support aimed at development and efficient realization of Ukrainian power sector export potential. The main factors promoting dynamics for electricity prices in Ukraine are substantiated. The evaluation and retrospective analysis of price competitiveness of Ukrainian electric power in the European power markets, revealed a reserve of price competitive advantages in the amount of about 20-30\%, which may increase in the medium term, especially taking into consideration the exchange devaluation in Ukraine.

Key words: competitiveness factors, export potential, power markets, electric power, price.

Вступ. В програмі першочергових заходів інтеграції Об'єднаної електроенергетичної системи (ОЕС) України в європейську [1] зазначається, що перспектива розвитку експорту електроенергії (ЕЕ) в західноєвропейському напрямку пов'язана 3 необхідністю розробки і проведення нової політики, яка повинна будуватися не на планах покриття очікуваного дефіциту ЕЕ в $\mathrm{CC}$, а на роботі в умовах жорсткої конкуренції, повноправної участі в європейському електроенергетичномуринку (ЕЕР). Сумарний експорт ЕЕ в країни $\mathrm{CС} \mathrm{та} \mathrm{СНД} \mathrm{в} 2012$ р. склав 624, в 2013 р.- 580 млн дол. США або близько 1\% від загального експорту товарів 3 України. Подальша реалізація експортного потенціалу (ЕП) ОЕС України визначатиметься динамікою міжнародної конкурентоспроможності електроенергетичних товарів під впливом комплексу факторів внутрішнього та зовнішнього походження.

Питання конкурентоспроможності товарів, в т.ч. міжнародної, розглядались у численних працях вітчизняних та зарубіжних фахівців 3 маркетингу, міжнародної економіки та торгівлі, стратегічного управління. Серед них варто відзначити роботи Азоєва Г.Л., Баумгартена Л.В., Герасимчука В.Г., Зав'ялова П.С., Котлера Ф., Ліфшиця І.М., Портера М., Фатхутдинова Р.А., Юданова А.Ю. та багатьох інших. Дослідження науковців носять як загальнотеоретичний, так і прикладний галузевий характер. Разом 3 тим недостатньо уваги присвячено електроенергетичним товарам, зокрема EE, які $є$ специфічними 3 точки зору можливості диференціації споживчих характеристик; характеру процесів виробництва, транспортування та споживання; факторів конкурентоспроможності та споживчого вибору. Відтак, 3 метою формування обгрунтованої державної секторальної та корпоративної зовнішньоторговельних політик, важливо визначити сучасні складові конкурентоспроможності електроенергетичних товарів на 
міжнародних ЕЕР та комплекс обумовлюючих іï факторів.

Постановка завдання. Метою статті є визначення сучасних факторів i складових конкурентоспроможності електроенергетичних товарів на європейських ринках, оцінка цінової конкурентоспроможності ЕЕ, виробленої в Україні.

Методологія. Теоретико-методологічною основою наукового дослідження $є$ принципи комплексного підходу, фундаментальні положення таких наукових дисциплін, як міжнародна торгівля, маркетинг, принципи концепції сталого розвитку суспільства. В дослідженні використовувались методи прикладного статистичного та економічного аналізу, статистичні дані Євростату, Державної служби статистики, Міністерства енергетики та вугільної промисловості, Національного банку України.

Результати дослідження. Під фактором конкурентоспроможності товару будемо розуміти умову чи рушійну силу, що визначає склад, величини i значимість кількісних та якісних параметрів його конкурентоспроможності. Електроенергетичні товари включають: 1) EЕ; 2) генеруючу та транспортну електричну потужність; 3) транзит EE; 4) інші системні послуги.

На товарних ринках при здійсненні вибору кінцевий споживач, як правило, приймає рішення на основі порівняльного аналізу альтернатив 3 урахуванням набору обмежень. Рішення про купівлю товару, за інших рівних обставин, базується на оцінці важливих для нього характеристик (параметрів). ЕЕ $є$ специфічним товаром в силу технологічних особливостей виробництва, транспортування та споживання, жорсткої стандартизованості якості та недоцільності диференціації іï технічних товарних властивостей.

Базуючись на аналізі пріоритетів енергетичної політики ЄС [2-4], ключовими сучасними складовими конкурентоспроможності $\mathrm{EE}$ на європейських ЕЕР будемо вважати: 1) цінову; 2) технічну; 3) екологічну; 4) інституційну. Виходячи 3 цього, головними внутрішніми факторами конкурентоспроможності ЕЕ, виробленої в Україні, та успішності експортної політики на ЕЕР СС, на наш погляд, $є$ такі:

- базова експортна ціна ЕЕ в національній валюті та можливості іiі диференціації ("цінове меню");

- курс національної валюти по відношенню до валют, в яких здійснюються розрахунки з імпортерами;

- гарантії підтримання якості EE, визначеної стандартами ENTSO-E;

- гарантії надійності електропостачання (наявність резервних генеруючих потужностей);

- технічні умови енергозабезпечення кінцевих споживачів (гнучкий графік постачання EЕ за рахунок маневреності генеруючих потужностей);

- екологічність (викиди $\mathrm{CO}_{2}, \mathrm{SO}_{2}, \mathrm{NO}_{x}$ та золи при виробництві ЕЕ; вид 
використаного первинного енергоресурсу).

Основними зовнішніми факторами, що впливатимуть на конкурентоспроможність ЕЕ та можливості реалізації ЕП є:

- оптові, зокрема біржові, та роздрібні ціни ЕЕ на зовнішніх ЕЕР;

- ціни на енергоресурси-замінники ЕЕ (природний газ тощо) та еластичність переключення споживачів;

- умови доступу та форми участі енергокомпаній України на зовнішніх EEP;

- умови доступу енергокомпаній України до електромереж країн i тарифи на передачу EE;

- енергетична політика СС (роль атомної енергетики; екологізація; розвиток відновлюваної енергетики), яка впливає на перспективні електробаланси країн, маневреність потужностей, ціни ЕЕ.

Конкурентоспроможність ЕЕ, виробленої в Україні, на зовнішніх ЕЕР протягом останніх 8-10 років обумовлюється відносно низькою ціною. Ї̈̈ рівень визначається істотною часткою ЕЕ, виробленої на АЕС (44-48\%), ТЕС на вугіллі (близько 40\%), вартість якого значно нижча вартості газу; відносно дешевою робочою силою; низьким рівнем екологічності об'єктів теплової генерації; низьким рівнем амортизаційних відрахувань, що пов'язано зі значним зменшенням вартості основних виробничих засобів. 3 урахуванням розвитку європейської енергетичної інтеграції України, зокрема членства в Енергетичному співтоваристві, планів інтеграції ОЕС України та енергосистем країн-членів ENTSO-E, в подальшому можна очікувати, що окрім перших двох, інші внутрішні фактори конкурентних переваг будуть поступово нівелюватись і обумовлювати зростання цін ЕЕ.

Згідно із Законом України "Про електроенергетику", енергокомпанії для здійснення експорту мають купувати ЕЕ на оптовому ринку ЕЕ (ОРЕ) України за поточною оптовою ринковою ціною. Тенденції зміни середніх експортних цін за країнами-імпортерами наведені в таблиці.

Таблиця

Динаміка середніх експортних цін на ЕЕ з ОЕС України, дол. США за 1 кВт-год.

\begin{tabular}{|l|c|c|c|c|c|c|c|c|}
\hline \multicolumn{1}{|c|}{ Країна } & 2006 & 2007 & 2008 & 2009 & 2010 & 2011 & 2012 & 2013 \\
\hline Польща & 0,025 & 0,028 & 0,050 & 0,053 & - & 0,067 & 0,044 & 0,046 \\
\hline Румунія & 0,031 & 0,060 & 0,062 & 0,058 & 0,063 & 0,08 & 0,061 & 0,056 \\
\hline Словаччина & 0,034 & 0,048 & 0,080 & 0,060 & 0,059 & 0,072 & 0,056 & 0,067 \\
\hline Угорщина & 0,035 & 0,054 & 0,072 & 0,057 & 0,061 & 0,079 & 0,058 & 0,055 \\
\hline $\begin{array}{l}\text { Середньозважена ціна } \\
\text { по країнам СС }\end{array}$ & 0,033 & 0,050 & 0,071 & 0,058 & 0,061 & 0,078 & 0,055 & 0,054 \\
\hline Білорусь & 0,019 & 0,025 & - & 0,040 & 0,045 & 0,059 & 0,052 & 0,062 \\
\hline Молдова & 0,024 & 0,029 & 0,041 & 0,049 & 0,080 & 0,061 & 0,056 & 0,069 \\
\hline РФ & 0,016 & 0,035 & - & - & 0,031 & 0,029 & 0,024 & 0,078 \\
\hline
\end{tabular}




\begin{tabular}{|l|c|c|c|c|c|c|c|c|}
\hline $\begin{array}{l}\text { Середньозважена ціна } \\
\text { по країнам СНД }\end{array}$ & 0,021 & 0,030 & 0,041 & 0,042 & 0,044 & 0,059 & 0,052 & 0,064 \\
\hline $\begin{array}{l}\text { Середньозважена } \\
\text { експортна ціна по } \\
\text { країнам СС та СНД }\end{array}$ & 0,027 & 0,040 & 0,060 & 0,053 & 0,049 & 0,068 & 0,054 & 0,058 \\
\hline $\begin{array}{l}\text { Співвідношення } \\
\text { експортних цін по } \\
\text { країнам СС та СНД }\end{array}$ & 1,57 & 1,67 & 1,73 & 1,38 & 1,39 & 1,32 & 1,06 & 0,84 \\
\hline
\end{tabular}

Джерело: власні розрахунки на основі даних Держстату України.

Примітка: середні иіни розраховані за даними про вартість ЕE в иінах DAF на основі вантажних митних декларацій, скоригованими за оперативними даними Міненерговугілля України.

Стале зростання середньозваженої експортної ціни по країнам ЄС протягом 2006-2008 рр. пояснюється збільшенням внутрішньої оптової ринкової ціни та сприятливою кон'юнктурою на зовнішніх ЕЕР. Зростання середньої експортної ціни в національній валюті продовжувалось і в наступні два роки, проте різка девальвація гривні в 2009 р., майже в 1,5 рази, спричинила зниження рівня ціни в дол. США в 2009 р. відносно 2008 р. на 18,3\%. Крім того, наслідком світової економічної кризи стало скорочення потреб в ЕЕ на ринках ЄС та викликане цим істотне зниження цін в 2009 2010 pp. За відносно стабільного обмінного курсу гривні (близько 7,97 грн за 1 дол. США) протягом 2009 - 2011 рр. середня експортна ціна по країнам СС зростала із середньорічним темпом 14,5\%. Проте протягом 2012-2013 рр. відбулось різке падіння кон'юнктурного характеру.

Відзначимо значну різницю в цінах $\mathrm{EE}$, яка постачалася в країни $\mathrm{CC}$ та СНД. Не зважаючи на те, що середня експортна ціна для країн СНД з 2006 р. по 2011 р. зростала із середньорічним темпом 22,1\%, протягом 2006 - 2008 рр. співвідношення експортних цін для країн ЄС та СНД коливалося в діапазоні 1,6-1,7. Це свідчить про вищу прибутковість експорту в країни СС, оскільки витрати на виробництво та експорт є практично еквівалентними. За період 2009 - 2011 рр. цінова диспропорція скоротилася до 1,3-1,4, а в 2012 р. нівелювалася. Така динаміка свідчить про високу залежність цін ЕЕ від стану поточної кон'юнктури зовнішніх ЕЕР, зокрема співвідношення попиту та пропозиції в біржовому секторі торгівлі.

Важливо дослідити тенденції середніх експортних цін в порівнянні із змінами внутрішньої середньої оптової ціни ЕЕ для експорту (рис. 1). Зазначимо, що експорт ЕЕ в Білорусь 32009 р., Молдову 32010 р., Угорщину, Польщу, Словаччину, Румунію 32012 р. здійснюється 3 урахуванням урядових розпоряджень, згідно з якими в експортних цінах не враховуються дотації, пов'язані 3 перехресним субсидіюванням, що дозволяє знижувати експортні ціни на величину близько 25\%. Середня експортна ціна ЕЕ для країн СС протягом 2006 - 2011 рр. перевищує внутрішню ціну. Натомість ціна для країн СНД є нижчою за внутрішню, причому в 2010 р. та 2011 р. 
відхилення між ними мінімізувались. Існування цих диспропорцій свідчить про резерви підвищення економічної ефективності експорту шляхом впровадження ринкових принципів ціноутворення на ЕЕР України.

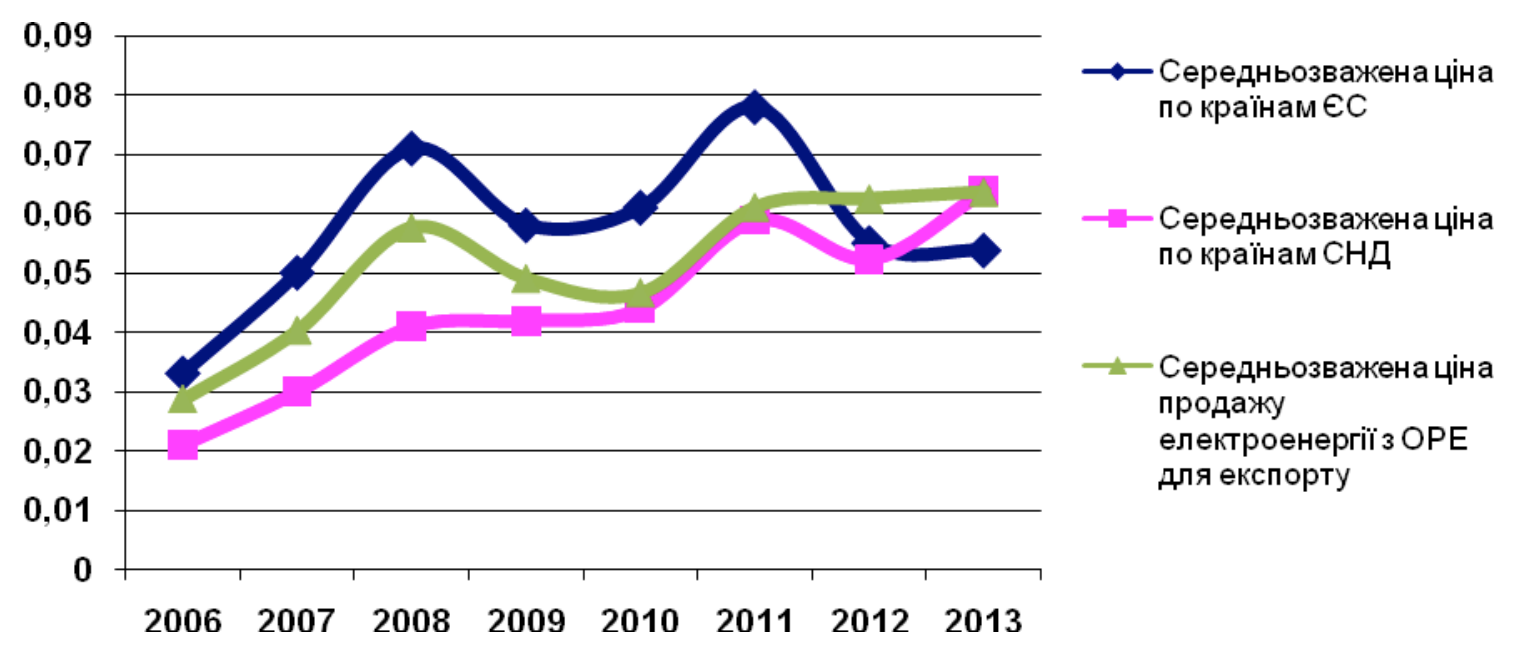

Рис. 1. Динаміка середніх експортних цін та оптової ціни на ЕЕР України, дол. США за 1 кВТ-год.

Джерело: побудовано за даними ДП "Енергоринок"

Одним з головних очікуваних ефектів функціонування нової моделі ЕЕР вважається зниження цін $\mathrm{EE}$, що має бути спричинене посиленням конкуренції між генеруючими, постачальними компаніями та скороченням посередницького ланцюжка. Разом з тим заслуговує на увагу досвід РФ, де за схожих умов відбувається лібералізація ЕЕР і дещо випереджає відповідні процеси в Україні. Внаслідок запровадження механізму двосторонніх договорів, частка яких станом на березень 2011 p. охоплює $35 \%$ EEP, спостерігається зворотний ефект зростання цін $\mathrm{EE}$ для промислових споживачів [5]. Серед основних чинників, що обумовлюють цей процес, виділяються такі: значні інвестиційні потреби для модернізації та створення нових енергетичних потужностей (близько 360 млрд дол. США до 2025 р.), які закладаються в ціну ЕЕ; зростання цін на природній газ; загальні інфляційні процеси. При цьому ціни та темпи їх зростання $€$ нерівномірними за регіонами та групами споживачів [6, с. 32]. На наш погляд, крім вищеназваних, важливою причиною, що провокує зростання цін $\mathrm{EE} \mathrm{в} \mathrm{РФ,} \mathrm{і} \mathrm{імовірно}$ призводитиме до подібних наслідків в Україні, $\epsilon$ невідповідність між інституційними передумовами розвитку конкуренції, вільного вибору постачальника кінцевими споживачами, 3 одного боку, та реальною конкурентною структурою ЕЕР - 3 іншого. Подібна цінова динаміка спостерігається і в Польщі, де протягом кризового 2009 р. ціни ЕЕ для кінцевих споживачів виросли на $32 \%$ (на $24 \%$ для населення та $39 \%$ для 
невеликих промислових споживачів) [7, с. 9].

Зазначимо, що особливості приватизації в РФ та Україні полягають в тому, що цей процес відбувається в період, коли рівень фізичного зносу основних виробничих засобів електроенергетики досяг критичних значень. Масштабна їх модернізація з метою підвищення надійності, економічності, екологічності потребує істотних капітальних інвестицій вже у середньостроковому періоді. Таким чином, за умови продовження лібералізаційних процесів на ЕЕР залучення інвестицій вимагатиме передбачення ринкових механізмів їх окупності шляхом урахування в ціні $\mathrm{EE}$, що спричинятиме iï зростання залежно від параметрів ефективності інвестицій, вартості інвестиційних ресурсів. За оцінками 2012 р. обсяг необхідних інвестицій в електроенергетику України до 2020 р. становить 382 млрд грн [8, с. 136].

В проекті Концепції діяльності НАЕК "Енергоатом" в період переходу та функціонування повномасштабного ринку двосторонніх договорів та балансуючого ринку ЕЕ України, зазначається, що ціна ЕЕ АЕС в 3-3,5 рази менша за оптову ринкову ціну та ціну ЕE TEC. У країнах з розвинутою економікою різниця цін ЕЕ ТЕС і АЕС складає близько $30 \%$, в РФ - 31\%. Крім того, ціна на EE AEC в Україні в 1,6 рази менша, ніж в РФ, хоча витрати на паливо для АЕС РФ приблизно у 2 рази нижчі. За рахунок штучного стримування зростання ціни ЕE AEC у рамках державного регулювання, стримується зростання оптової ринкової ціни і ціни для кінцевих споживачів, що відбувається переважно за рахунок скорочення інвестиційних програм НАЕК "Енергоатом" [9]. Відповідно економічні інтереси НАЕК "Енергоатом" та ринкові можливості сприятимуть зростанню ціни ЕE АЕС та підвищенню середнього рівня її ціни на ЕЕР України.

Інтенсифікація використання ВДЕ в Україні також спричинятиме зростання середньої ціни $\mathrm{EE}$, хоча й частка ВДЕ в електробалансі нині $\epsilon$ відносно незначною (близько 0,6\%). Окрім того, одним з основних факторів перманентного характеру є зростання цін на первинні енергоресурси (вугілля, природний газ, уран). Вищенаведені чинники спричинятимуть зростання внутрішніх цін ЕЕ. Разом $з$ тим з точки зору реалізації ЕП важливими $є$ не абсолютні значення, а співвідношення цін на внутрішньому та зовнішніх EEP.

Основними факторами динаміки цін ЕЕ в країнах $Є \mathrm{C} \epsilon$ такі: підвищення цін на первинні енергоресурси; поступове скорочення виробництва EE AEC; інтенсифікація використання ВДЕ; масштабні інвестиції в розвиток внутрішніх та міждержавних електромереж. Відповідний план розвитку мереж ENTSO-E на 2010-2019 pр. містить 471 проект національного та міжнародного характеру [10, с. 5]. За орієнтовними оцінками інвестиції для його реалізації на перші п'ять років складуть 23-28 млрд євро. Цільовими характеристиками проектів є: приєднання до мереж електростанцій на ВДЕ; 
підвищення надійності постачання ЕЕ; диверсифікація електропостачання; скорочення технологічних витрат на передачу EЕ; підвищення пропускної спроможності міждержавних ЛЕП.

Середні ціни ЕЕ вкраїнах Свропи для кінцевих споживачів (промислових підприємств зрічним споживанням 2-20 тис. МВт-год. та населення - 2-5 тис. кВТ-год.) в 2012 р. наведені на рис. 2.

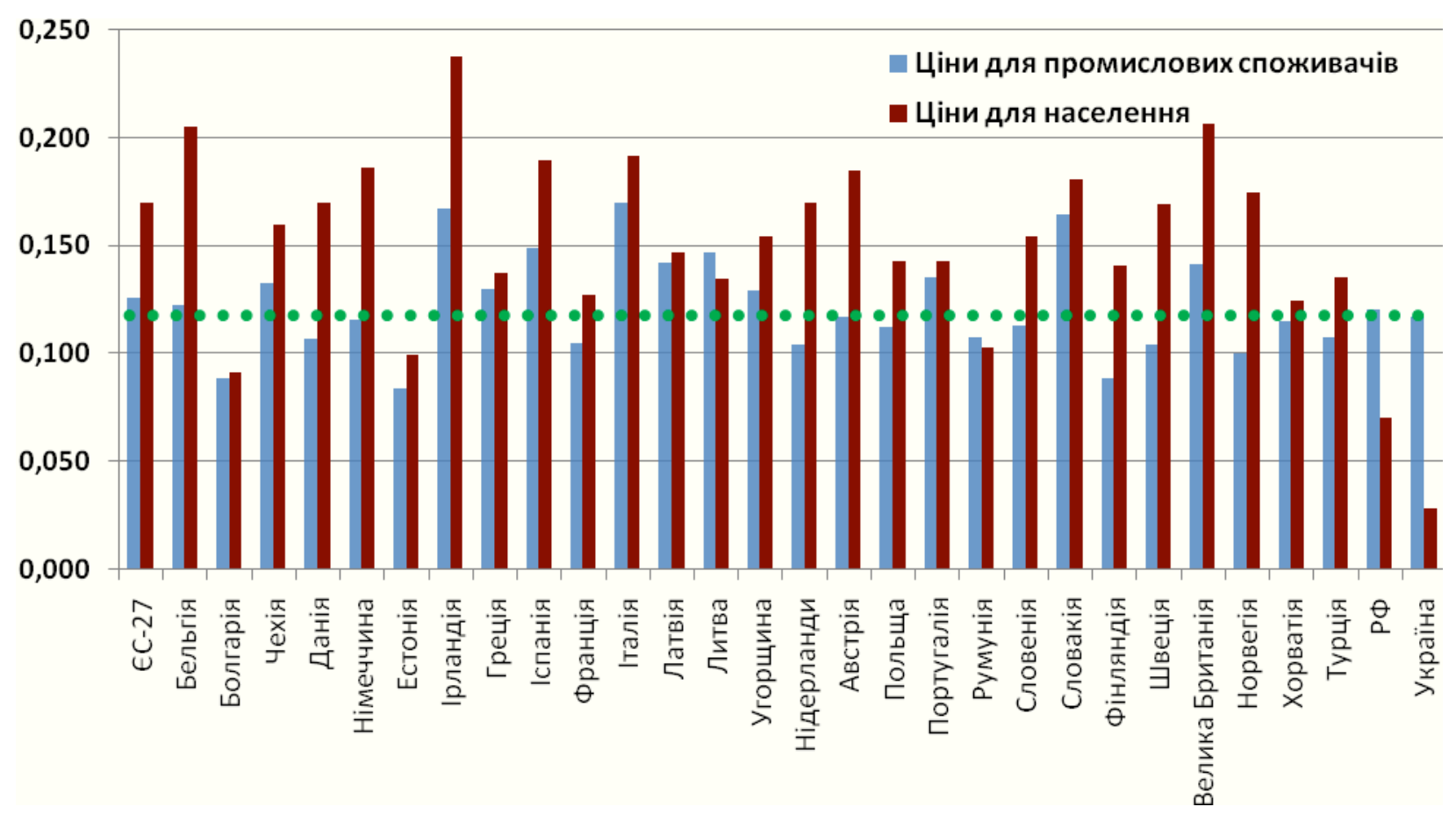

Рис. 2. Варіація цін ЕЕ для промислових споживачів та населення в 2012 р., дол. США за 1 кВт-год.

Джерело: побудовано за даними Свростату та НКРЕ

Для коректності порівняння ціни на рис. 2 наведені без урахування податків, величини яких істотно різняться за країнами. В цілому рівень цін на EЕР країн $Є С$ є вищим ніж в Україні. Значна варіація цін спостерігається і між країнами $Є С$ : ціни в електропрофіцитних країнах, як правило, нижчі ніж в електродефіцитних. Серед торговельних партнерів України в електропрофіцитних Польщі й Румунії ціни $\mathrm{EE}$ нижчі порівняно 3 електродефіцитними Словаччиною і Угорщиною. При порівнянні даних табл. 1 та рис. 2 видно, що ціни для промспоживачів в останніх двох країнах перевищують відповідні експортні ціни ЕЕ з України в2,9 та 2,2 рази.

При цьому необхідно зазначити, що на європейських ринках спостерігаються сталі процеси розвитку біржової торгівлі ЕЕ. Тому все важливішим індикатором у зовнішній торгівлі стають оптові регіональні біржові ціни ЕЕ базового та пікового періодів споживання. Найбільшими енергетичними біржами Європи є ЕpexSpot (Франція, Німеччина, Австрія, 
Швейцарія), NordPoolSpot (Норвегія, Швеція, Фінляндія, Данія, Естонія, Латвія, Литва). Також функціонують регіональні біржі, напр., РХЕ (Чехія, Угорщина, Словаччина) та національні. Аналіз показує високу подібність динаміки експортних цін на ЕЕ з України та європейських біржових цін, що свідчить про орієнтацію експортної політики енергокомпаній України на цінові тенденції європейських енергетичних бірж. В цілому порівняння відповідних рівнів цін показує наявність запасу цінових конкурентних переваг енергокомпаній України в розмірі близько 20-30\%, який може зберегтись і навіть зростати в середньостроковому періоді, особливо враховуючи девальвацію національної валюти.

Висновки. Наукова новизна роботи полягає у подальшому розвитку науково-методичних та практичних підходів до оцінки й забезпечення міжнародної конкурентоспроможності $\mathrm{EE}$. 3 урахуванням пріоритетів середньо- та довгострокової енергетичної політики СС, визначено ключові сучасні складові конкурентоспроможності ЕЕ на європейських ЕЕР, серед яких: цінова; технічна; екологічна; інституційна. Це дозволяє ідентифікувати напрями удосконалення державної секторальної та корпоративної зовнішньоторговельних політик з метою підвищення ефективності експортної діяльності енергокомпаній України.

Виходячи із запропонованих складових міжнародної конкурентоспроможності EЕ, визначено комплекс внутрішніх та зовнішніх чинників конкурентоспроможності ЕЕ, виробленої в Україні, для здійснення моніторингу, аналізу та прогнозування їхньої динаміки, що сприятиме комплексному обгрунтуванню рішень, спрямованих на розвиток та реалізацію ЕП електроенергетики України.

Обгрунтовано основні фактори перспективної динаміки цін на ЕE в Україні, які доцільно враховувати при прогнозуванні цін та цінової конкурентоспроможності $\mathrm{EE}$ на європейських EЕP. Оцінка та ретроспективний аналіз міжнародної цінової конкурентоспроможності ЕЕ, виробленої в Україні, дозволили виявити запас конкурентних переваг на європейських ЕЕР в діапазоні 20-30\%. Він імовірно буде зберегтись і навіть зростати в середньостроковому періоді, особливо враховуючи фактор девальвації національної валюти.

Перспективами подальших досліджень $є$ оцінка впливу виконання екологічних вимог ЄС до роботи об'єктів теплової генерації, інноваційноінвестиційних проектів модернізації електростанцій, передбаченої національною енергетичною стратегією та міжнародними зобов'язаннями України, на перспективну динаміку цін та міжнародну конкурентоспроможність ЕЕ, виробленої в Україні.

\section{Література:}


1. Першочергові заходи інтеграції об’єднаних енергетичних систем України до об'єднаних енергетичних систем СС [Електронний ресурс] // Міністерство енергетики та вугільної промисловості України. http://mpe.kmu.gov.ua/fuel/doccatalog/document?id=153636.

2. Energy 2020: A strategy for competitive, sustainable and secure energy [Електронний pecypc] // Сайт $\mathrm{CC} \mathrm{-}$ lex.europa.eu/LexUriServ/LexUriServ.do?uri=CELEX:52010DC0639:EN:NOT.

3. Energy Roadmap 2050 [Електронний pecypc] // Сайт $\mathrm{CC} \mathrm{-} \mathrm{Режим} \mathrm{доступу:}$ http://ec.europa.eu/energy/publications/doc/2012_energy_roadmap_2050_en.pdf.

4. Sustainable, secure and affordable energy for Europeans [Електронний ресурс] // Сайт СC - Режим доступу: http://europa.eu/pol/ener/flipbook/en/files/energy.pdf.

5. Алексеева О. Государство не пускает энергию на рынок [Електронний ресурс]. Режим доступу: http://www.gazeta.ru/financial/2011/03/17/3557685.shtml.

6. Кудияров С. Всегда есть другой путь // Эксперт. - №27. - 2011. - С. 32-34.

7. National Report of the Energy Regulatory Office in Poland to the European Commission in 2010 [Електронний pecypc]. - Режим доступу: http://www.energyregulators.eu/portal/page/portal/EER_HOME/EER_PUBLICATIONS/NATIONAL_REPORTS/N ational\%20Reporting\%202010/NR_En/E10_NR_Poland-EN.pdf.

8. Енергетична стратегія України на період до 2030 р. [Електронний ресурс] // Міністерство енергетики та вугільної промисловості України. - Режим доступу: http://mpe.kmu.gov.ua/fuel/control/uk/doccatalog/list?currDir=50358.

9. Концепція діяльності ДП НАЕК "Енергоатом" в період переходу та функціонування повномасштабного ринку двосторонніх договорів та балансуючого ринку електричної енергії України [Електронний ресурс]. - Режим доступу: http://www.energoatom.kiev.ua/ua/arch?_m=pubs\&_t=rec\&id=29184.

10. Ten-Year Network Development Plan, 2010 [Електронний ресурс]. - Режим доступу: https://www.entsoe.eu/system-development/tyndp/tyndp-2010/. 